\title{
Future soil loss in highland Ethiopia under changing climate and land use
}

\author{
Desalew Meseret Moges ${ }^{1}$ (D) Alexander Kmoch ${ }^{2} \cdot$ H. Gangadhara Bhat ${ }^{3} \cdot$ Evelyn Uuemaa $^{2}$
}

Received: 13 November 2018 / Accepted: 16 February 2020

(C) Springer-Verlag GmbH Germany, part of Springer Nature 2020

\begin{abstract}
Soil erosion caused by climate and land-use changes is one of the biggest environmental challenges in highland Ethiopia. The aim of this study was to assess the future soil erosion risks and evaluate the potential conservation measures in the Rib watershed, northwestern highland Ethiopia. We used the HadGEM2-ES model with a moderate greenhouse gas (GHG) concentration scenario (RCP4.5) to project the future climate. The future land-use patterns were predicted using the CA-Markov model. We integrated the RUSLE model with GIS to estimate the spatial distribution of soil loss and identify erosion risk areas. We found that the Rib watershed is highly vulnerable to future climate and land-use changes, leading to a high soil erosion risk. Despite slight growth of forest cover during the study period, the total soil loss for the watershed was estimated to be $7.93 \times 10^{6} \mathrm{t} \mathrm{year}^{-1}$ in 2017 and was predicted to increase to $9.75 \times 10^{6} \mathrm{t} \mathrm{year}^{-1}$ in 2050 , an increase of about $23 \%$. The increase in forest cover was due to the expansion of the area of eucalyptus plantations which are more prone to erosion. Moreover, field survey showed that the residual native forests are sparsely vegetated and mostly used for cattle grazing, increasing the erosion risk even more. In contrast, the combined use of afforestation with native trees and physical soil conservation measures in the upper areas of the catchment could decrease soil loss by $62 \%$. Our results stress the importance of combining soil conservation measures, including converting eucalyptus plantations to native forests, to mitigate the effects of future climate change and increased agricultural production on soil erosion.
\end{abstract}

Keywords Modeling $\cdot$ HadGEM2-ES model $\cdot$ RUSLE model $\cdot$ CA-Markov model $\cdot$ GIS $\cdot$ Nature-based solutions

\section{Introduction}

Soil is a vital part of the terrestrial ecosystem that contributes to the delivery of primary ecosystem services (Pereira et al.

Communicated by Diana Sietz

Electronic supplementary material The online version of this article (https://doi.org/10.1007/s10113-020-01617-6) contains supplementary material, which is available to authorized users.

Desalew Meseret Moges

mdessalew@gmail.com

1 Department of Geoinformatics, Mangalore University, Mangalagangotri 574199, India

2 Department of Geography, University of Tartu, Vanemuise 46, 51003 Tartu, Estonia

3 Department of Marine Geology, Mangalore University, Mangalagangotri 574199, India
2018). Healthy soil performs a large number of crucial functions, including the production of food and biomass products, storage and filtration of carbon and water, and regulation of carbon dioxide and other emitted gases (Breure et al. 2018). Therefore, soils must be protected and used in a sustainable way. Keesstra et al. (2018) suggest that nature-based solutions, including solutions that target soils and landscapes, are cost-effective long-term solutions for hydrological risks and land degradation, and can support sustainable soil use.

However, water-induced soil erosion has become a major ecological and environmental problem, as it leads to a continuous reduction of soil quality and productivity in many places around the world (Mekuriaw et al. 2018). Although soil erosion is a global phenomenon, it has become particularly rapid and severe in highland Ethiopia due to complex interactions among anthropogenic and natural factors. Annually, Ethiopia loses more than $1.5 \times 10^{9} \mathrm{t}$ of topsoil from the highlands due to erosion, and this soil could have added about $1.5 \times 10^{6} \mathrm{t}$ of grain to the country's annual harvest (Tamene and Vlek 2008). 
This makes soil erosion one of the biggest environmental constraints to agricultural sustainability, food security, and rural development in highland Ethiopia (Teshome et al. 2016).

Climate and land-use changes are among the most important agents that are causing soil erosion in highland Ethiopia (Tadesse et al. 2017; Bekele et al. 2018). Deforestation and the expansion of cropland in Ethiopia have already reached the highest level observed in the past several centuries. Currently, cropland in most parts of the Ethiopian highlands occupies more than $80 \%$ of the total land, whereas natural forest covers less than $3 \%$, and much of this forest is significantly degraded. About $40 \%$ of Ethiopia's total land was once covered by various types of natural forest, but this proportion had shrunk to $16 \%$ in the 1950 s and continued to decrease, reaching $2.7 \%$ in the 1990 s (FAO 2010). Cebecauer and Hofierka (2008) and Mohammad and Adam (2010) note that such a rapid reduction in forest cover significantly increases surface runoff and soil erosion in various ways. Forest reduces the rate of soil erosion by stabilizing soils and enhancing their water-holding capacity. Thus, any kind of forest destruction directly increases soil losses by facilitating surface runoff. Land-use change also markedly affects soil organic carbon through its effect on humification, decomposition, and mineralization of soil organic matter, which in turn influences the rate of soil loss because organic matter increases soil cohesion and water retention (Basaran et al. 2007). Therefore, by properly adjusting land-use patterns, soil properties can be greatly improved and runoff and soil erosion rates can be reduced (Zhang et al. 2008).

In addition to land-use change, climate change represents one of the critical global environmental issues that is affecting hydro-meteorological processes and increasing surface runoff and soil erosion. One of the most direct effects of climate change is due to a change in the erosive power of the rainfall (Pruski and Nearing 2002; Simonneaux et al. 2015). Higher rainfall modifies the hydrological conditions in a given area and influences the infiltration and runoff rates (Pruski and Nearing 2002), which in turn causes an increase in surface runoff and soil erosion even when land use has not changed (Klik and Eitzinger 2010). Climate change also determines plant biomass production and decomposition, evapotranspiration, soil microbial activities, and changes in land use (Bussi et al. 2014; Williams et al. 1996), all of which control the rate of soil loss in different ways. Unless proper soil protection practices are carried out, the increasing rate of rainfall erosivity is predicted to cause an extraordinary increase in soil erosion worldwide, with serious implications for economic, social, and environmental sustainability (Plangoen et al. 2013; Paroissien et al. 2015). The economic implications of climate change are particularly severe in developing countries such as Ethiopia for many reasons, including high dependence on rainfed agriculture, low adaptive capacity, and high ecological and social vulnerability (Nigussie et al. 2018).
Although the separate influences of climate change and land-use change on soil erosion have been frequently investigated around the world (Nyssen et al. 2009; Nunes et al. 2013; Routschek et al. 2014; Moges and Bhat 2017), few modeling studies (e.g., Asselman et al. 2003; Bussi et al. 2016) have addressed their joint effects. Previous studies also showed that there is large uncertainty in the predicted effects of climate change on soil loss due to differences in the adopted emission scenarios and models used for the predictions. Furthermore, the effectiveness of conservation measures remains poorly understood in the context of modeling soil erosion risks under the framework of climate and land-use changes. Thus, it is increasingly necessary to assess the joint effects of future climate and land-use changes on soil erosion and evaluate the impact of the potential conservation measures, particularly in erosion-prone areas such as highland Ethiopia.

Several empirical models have been developed to assess the response of soil erosion to changing climate and landuse conditions. The revised universal soil loss equation (RUSLE; Renard et al. 1997) is among the most widely used empirical models due to its structural simplicity (Volk et al. 2010), compatibility with many geospatial technologies (Bhandari et al. 2015), and feasibility for studies at a watershed scale (Prasannakumar et al. 2012). The aim of the present study was to evaluate the future impacts of climate and landuse changes on soil loss in a representative watershed (the Rib watershed, in highland Ethiopia) using the RUSLE model integrated with geographical information system (GIS) software. We also assessed the effectiveness of several conservation measures in reducing soil erosion rates. We selected the Rib watershed as a case study because it is one of the most severely eroded watersheds in highland Ethiopia, mainly due to changes in rainfall erosivity, land-use changes, the widespread use of intensive agriculture, and limited use of conservation measures.

\section{Materials and methods}

\section{Study area}

This study was conducted in the Rib watershed, which is located in the northwestern highlands of Ethiopia (Fig. 1). It covers an area of about $1975 \mathrm{~km}^{2}$, and 376,256 residents rely on agrarian activities for their livelihood. The watershed's population is growing, which will increase the pressure on agricultural land. The watershed's topography is generally rugged and mountainous, with the elevation ranging from $1758 \mathrm{~m}$ above sea level (m a.s.l.) in the western part to $4104 \mathrm{~m}$ a.s.l. in the southeastern part. The watershed has a climate ranging from humid to sub-humid and contains several ecosystems and resource types. The average annual precipitation from 1973 to 2016 was approximately $1502 \mathrm{~mm}$ 


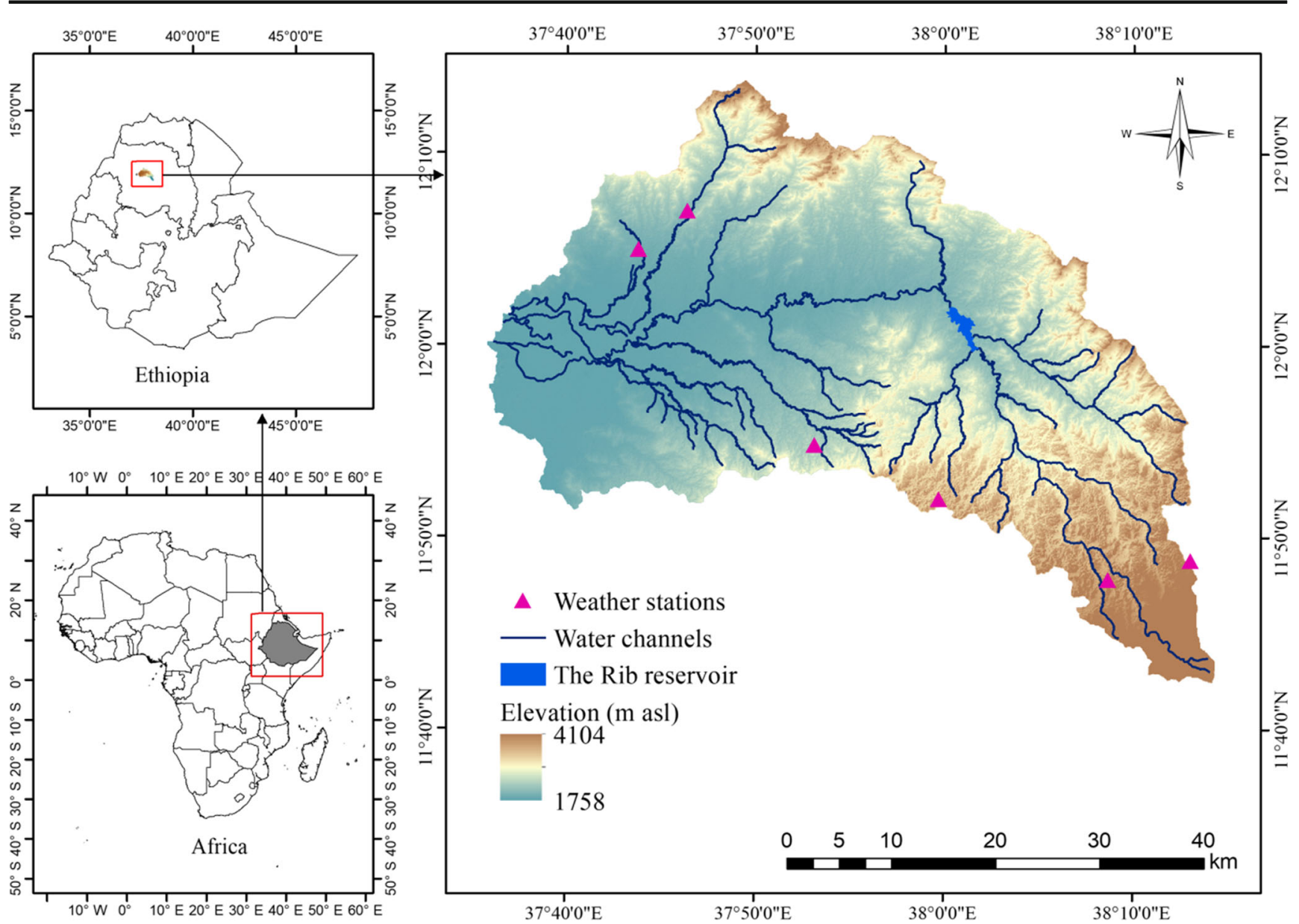

Fig. 1 Location and topography of the study area

(Moges and Bhat 2018). The area receives the maximum amount of rain between June and September (the main rainy season) and the minimum amount from October to February (the dry season), when there is little or no rain. The mean annual temperature ranges from 15 to $17{ }^{\circ} \mathrm{C}$. Moges and Bhat (2018) revealed that about $88 \%$ of the watershed is occupied by agricultural land, whereas forest covers only $3.5 \%$ of the catchment. The major rainfed cereal crops grown in the area include barley, wheat, tef, maize, and legumes such as beans and peas (Moges and Bhat 2017). The watershed contains a wide range of soils derived from weathered volcanic rock. Based on the FAO-UNESCO soil classification system, the four major soil types (which account for more than $80 \%$ of the soils in the watershed) are Luvisols, Vertisols, Leptosols, and Regosols.

\section{Land-use data sources and classification}

We analyzed the land-use change patterns and trends in the watershed based on remotely sensed images from three reference years (1986, 2001, and 2017). Time-series Landsat data with a path/row of 169/052 were obtained from the Earth Resources Observation and Science data center (https:// www.usgs.gov/centers/eros) of the US Geological Survey. All images were geometrically co-registered to the Universal Transverse Mercator (UTM) projection coordinate system (WGS 84 datum, UTM Zone 37N), and pre-processed using the ERDAS IMAGINE 2014 software. The six major land uses were cropland, grassland, shrubland, forest, built-up land, and bodies of water, so we focused on these uses in our change-detection analysis. We used a hybrid land-use classification technique that combines unsupervised classification (using the ISODATA clustering algorithm) with supervised classification to assign pixels in the image to one of the land-use classes. We used field data gathered through field observations, interviews with key informants, and focus group discussions to validate the land-use classification and identify soil conservation measures. Four focus group discussions, each group comprised of 8 to10 persons, and several indepth interviews with 18 key informants were held between November 2016 and May 2017. The group discussions and interviews were carried out by the corresponding author. Interviewed individuals included village administrators, watershed management committee members, and agricultural experts who had deep first-hand knowledge about the landuse types and their change history, watershed degradation and 
management practices, farming systems, and other socioeconomic and biophysical aspects of the watershed.

\section{Land-use change modeling}

We used the CA-Markov model implemented in the IDRISI Selva software (Eastman 2012) to simulate the future land-use patterns in 2050. We used Landsat-based land-use maps from 1986, 2001, and 2017 for model validation and creation of transition potential maps. In this context, transition potential maps represent the probability of a pixel for conversion into a particular land-use type. Land-use changes result from complex and strong interactions between people and their ecological and social environments (Lambin et al. 2001). Therefore, it is important to consider the set of potential factors and constraints during the creation of the transition potential maps. In this study, we selected biophysical parameters (e.g., elevation, slope, soil fertility) and accessibility factors (e.g., distances from roads, rivers, and towns) based on the knowledge and experience of the researchers, a review of the scientific literature, and the opinions of the farmers and local experts. For example, steep slopes limit farming practices and the expansion of built-up areas; however, such areas can be suitable for afforestation.

The remnant natural forests, existing water surfaces (e.g., the Rib Reservoir), and major road networks were considered to be constraints and were excluded from future land-use change. Fig. S1 and Table S1 in the Supplementary Material summarize the potential factors and constraints considered in our land-use modeling. We evaluated the contribution of the variables to predict land-use change by computing Cramer's $V$ statistic, a measure of the association between variables, with a value ranging from 0 (no association) to +1 (complete association). We found moderate $V$ values ( 0.25 to 0.58 ) the variables under consideration. We used the fuzzy set membership function approach provided by IDRISI to generate the individual suitability maps. Fuzzy membership standardizes continuous factors into the desired range using one of a number of membership function shapes (i.e., sigmoid, J-shaped, linear, user-defined) and types (i.e., monotonically increasing, monotonically decreasing, symmetrical) (see Supplementary Material Table S2). The fuzzy membership functions influence the probability of transition to a given land-use class by governing the shape and direction of the changes based on the values (control points) allocated to the factor images (Eastman 2012). For example, choosing a monotonically decreasing function would mean that the smallest distance value has the highest probability score, and as the distance increases, probability becomes smaller.

After defining the fuzzy set membership functions, we used the analytical hierarchy process (Saaty 1980) to consider the importance of the variables in land-use change (see supplementary Material Table S2). We applied the weight to the factors according to their rank in the analytical hierarchy. The factor with the highest land-use change potential was given the highest score (rank 1), the factor with the nexthighest potential was given the second highest score (rank 2 ), and so on. Finally, we used the multi-criteria evaluation module in IDRISI to generate the transition potential maps for each land-use class with 0 indicating a complete lack of suitability (not suitable) and 255 indicating the highest suitability for conversion from one class into another (see Supplementary Material Fig. S2).

The accuracies of the simulated land uses were evaluated based on the kappa index and visual inspection. The overall kappa was $93.5 \%$, which we considered to be satisfactory for the future land-use prediction.

\section{Climate change modeling}

Both the baseline and future climate data were analyzed in this study. The baseline climate data were used to estimate the baseline soil loss and validate the predicted climate scenarios. The daily precipitation and temperature records from 1973 to 2017 obtained from the Ethiopian National Meteorological Agency (www.ethiomet.gov.et) were used for baseline climate analysis. We considered five commonly used global circulation models (see Supplementary Material Table S3) using the moderate GHG concentration scenario (RCP 4.5) for future climate analysis. We evaluated the performance of the selected models by comparing the simulated rainfall data with observed data from 1986 to 2017 using three statistical measures: the root-mean-square error, coefficient of variation, and correlation coefficient (see Supplementary Material Table S4). Among the models evaluated, HadGEM2-ES performed the best in terms of capturing well-distributed rainfall and temperature values; we, therefore, selected it for use in the present study. The HadGEM2-ES model is a coupled Earth system model developed by the Met Office Hadley Centre for the Coupled Model Intercomparison Project Phase 5 (CMIP5) centennial simulations (https://portal.enes.org/). We downloaded the downscaled products of the HadGEM2-ES model for the period from 2018 to 2050 from the MarkSim data distribution center (http://gismap.ciat.cgiar.org/ MarkSimGCM/) for subsequent analysis.

\section{Soil erosion modeling}

We used the RUSLE model for erosion modeling. RUSLE is the revised form of the USLE model (Wischmeier and Smith 1978), with substantial improvements in its ability to account for the effects of soil surface roughness and local weather on the prediction of soil loss and sediment delivery. The RUSLE model can be integrated with the IDRISI software to enable estimation of soil loss for groups of pixels based on the slope, orientation, and slope length, which can be adjusted by the 
user (Chen et al. 2008). Such a slope-based estimation of soil loss is particularly useful in areas like the Rib watershed, where the slope strongly affects the development of rapid and erosive runoff. RUSLE requires six parameters, as follows:

$A=R \times K \times L S \times C \times P$

where $A$ is the average soil loss per unit area $\left(\mathrm{t} \mathrm{ha}^{-1}\right.$ year $\left.^{-1}\right)$, and the remaining factors are coefficients: $R$ for runoff due to rain (MJ mm ha ${ }^{-1} \mathrm{~h}^{-1}$ year $^{-1}$ ), $K$ for soil erodibility (t ha h $\mathrm{MJ}^{-1} \mathrm{ha}^{-1} \mathrm{~mm}^{-1}$ ), LS for topography, $C$ for the soil and land cover, and $P$ for conservation practices. The calculation methods we used for these coefficients are presented in the following sections.

\section{Rainfall erosivity factor}

$R$ represents the erosive force of rainfall as a function of the rainfall volume, intensity, and duration (Alexakis et al. 2013). In the RUSLE model, the rainfall erosivity is estimated using the total storm energy and 30-min intensity $\left(E I_{30}\right)$ of the rainfall (Renard et al. 1997). However, computation of the $R$ values based on such intensive rainfall records is unrealistic in areas such as our study site that cannot provide data with this temporal resolution. Instead, we adopted an empirical formula developed by Hurni (1985) to estimate $R$ values in Ethiopia:

$R=-8.12+(0.562 P)$

where $R$ is rainfall-runoff erosivity and $P$ is the mean annual precipitation. To compute the $R$ values, we converted the monthly rainfall values for the baseline period (1973 to 2017) and the future scenario (2018 to 2050) into the mean annual rainfall. We then developed iso-erosivity maps (Fig. 2a, b) by interpolating the mean annual rainfall at the meteorological stations shown in Fig. 1 to the entire watershed in the ArcGIS software using an ordinary kriging method based on a Gaussian function.

\section{Soil erodibility factor}

$K$ represents the effect of soil properties and soil profile characteristics on soil loss. It can be best obtained from experimentally measured soil properties such as the soil's permeability, structure, and organic matter content. However, the absence of such detailed soil property data in most developing countries, including Ethiopia, often makes it infeasible to use empirical $K$ values. As an alternative, researchers (e.g., Bewket and Teferi 2009; Brhane and Mekonen 2009) have suggested values of $K$ for use in Ethiopia based on the soil color, which is believed to be a good proxy for soil physical properties. The $K$ values in the present study were therefore generated based on the soil color. The red, brown, and black soils were identified, and the corresponding $K$ values were $0.25,0.20$, and 0.15 , respectively (Fig. $2 \mathrm{c}$ ).

\section{Topographic factor}

$L S$ represents the effect of topography on soil loss, where $L$ represents the effect of slope length on erosion and $S$ reflects the influence of slope on erosion. Various empirical formulas have been developed around the world to determine the value of $L S$. In the present study, we generated an $L S$ map of the study area based on a $30 \mathrm{~m}$-resolution Shuttle Radar Topography Mission (SRTM) digital elevation model downloaded from the US Geological Survey data center. We used the equation of Moore and Burch (1986) to calculate the $L S$ factor in ArcGIS (ESRI 2011).

$L S=\left(F_{a c} \times \frac{C S}{22.13}\right)^{0.4} \times\left(\frac{\sin (\text { slope })}{0.0896}\right)^{1.3}$

where $L$ is the slope length factor, $S$ is the slope steepness factor, $F_{\mathrm{ac}}$ is a raster-based flow accumulation, and $C S$ is the grid resolution. $F_{\mathrm{ac}}$ was computed from the digital elevation model using the Arc Hydro tools in ArcGIS (Fig. 2d).

\section{Cover management factor}

$C$ represents the effects of cropping and management practices on soil erosion (Wischmeier and Smith 1978). Its value is largely controlled by the surface vegetation, land use, soil surface roughness, and soil moisture (Farhan and Nawaiseh 2015). With values ranging from 0 (well-protected soils) to 1 (bare soil), $C$ is strongly related to land use (Ferreira et al. 2016). In this study, $C$ values were determined based on the most recent (2017) and predicted future (2050) land-use data. We used the methods of Hurni (1985), Bewket and Teferi (2009), and Haregeweyn et al. (2017) to assign $C$ values to each land-use class. The spatial distributions of $C$ for the current and future scenarios are given in Fig. 2e-g.

\section{Conservation practice factor}

$P$ represents the ratio of soil loss after the implementation of specific conservation practices to the corresponding soil loss before these practices (Renard et al. 1997). It is primarily used to assess the effects of farming practices and soil and water conservation measures on soil loss (Taye et al. 2018). The values of $P$ range from 0 (well-conserved areas) to 1 (no conservation practice). Our field surveys indicated that soil and water conservation activities are not widely practiced in the Rib watershed. On the other hand, the farmers commonly use contour plowing to reduce erosion from surface runoff. In areas where contour plowing is widely practiced, Hurni 

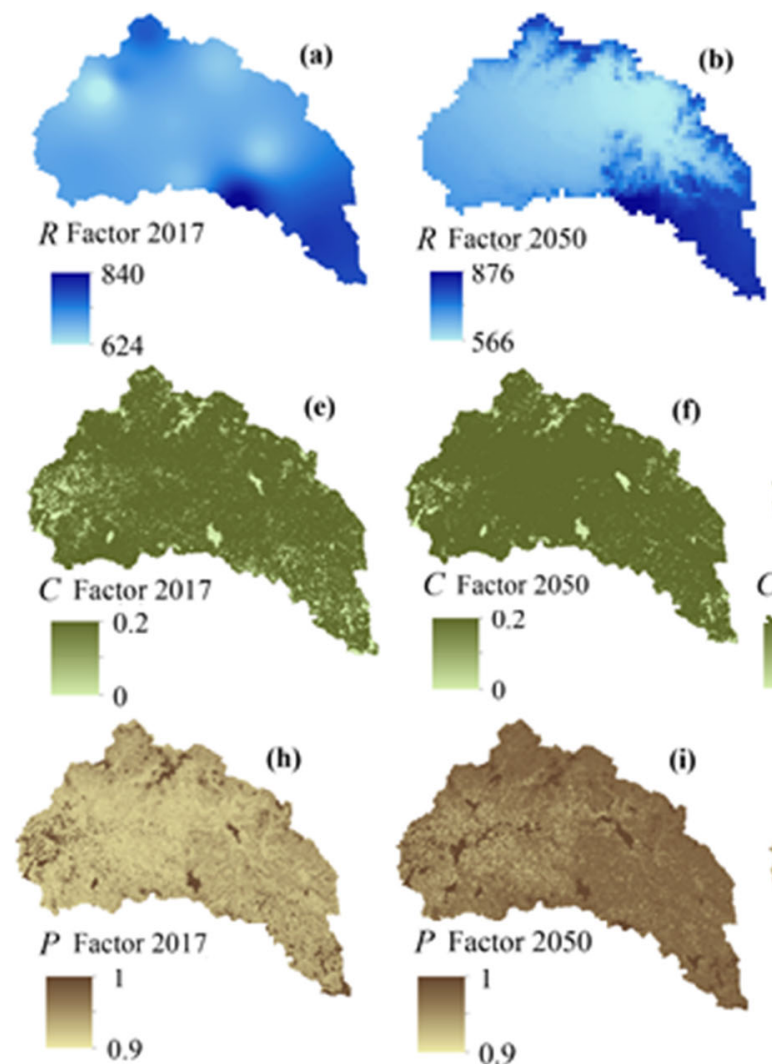

Fig. 2 Spatial distributions of the RUSLE input layers. a $R$ factor for the baseline (1973 to 2017) condition, $\mathbf{b} R$ factor for the future scenario (2018 to 2050), c $K$ factor, $\mathbf{d} L S$ factor, e $C$ factor for the baseline condition, $\mathbf{f} C$ factor for the future scenario, $\mathbf{g} C$ factor for the future scenario after

(1985) and Taye et al. (2018) suggested using $P$ values of 0.9 and 1.0 for agricultural and non-agricultural lands, respectively. We used a similar technique in the present study to assign $P$ values to the whole watershed during the baseline period (2017). However, for the future scenario (2050), we chose areas with a slope greater than $20 \%$ as target areas for soil conservation practices. We, therefore, assigned a $P$ value of 0.5 (Hurni 1985) to these areas. For areas with a smaller slope, we used the value from the baseline period. The spatial distributions of $P$ in the current situation and future scenarios are given in Fig. $2 \mathrm{~h}-\mathrm{j}$.

\section{Scenarios and their descriptions}

Based on the current and future climate and land-use datasets, we designed one baseline scenario (based on the conditions in 2017) and four future scenarios.

\section{Scenario 1: baseline}

This scenario assesses the current rate of soil loss in the watershed based on the current climate, land use, and management practices. The $R$ values were computed from historical (1973 to 2017) rainfall data collected at gauging stations
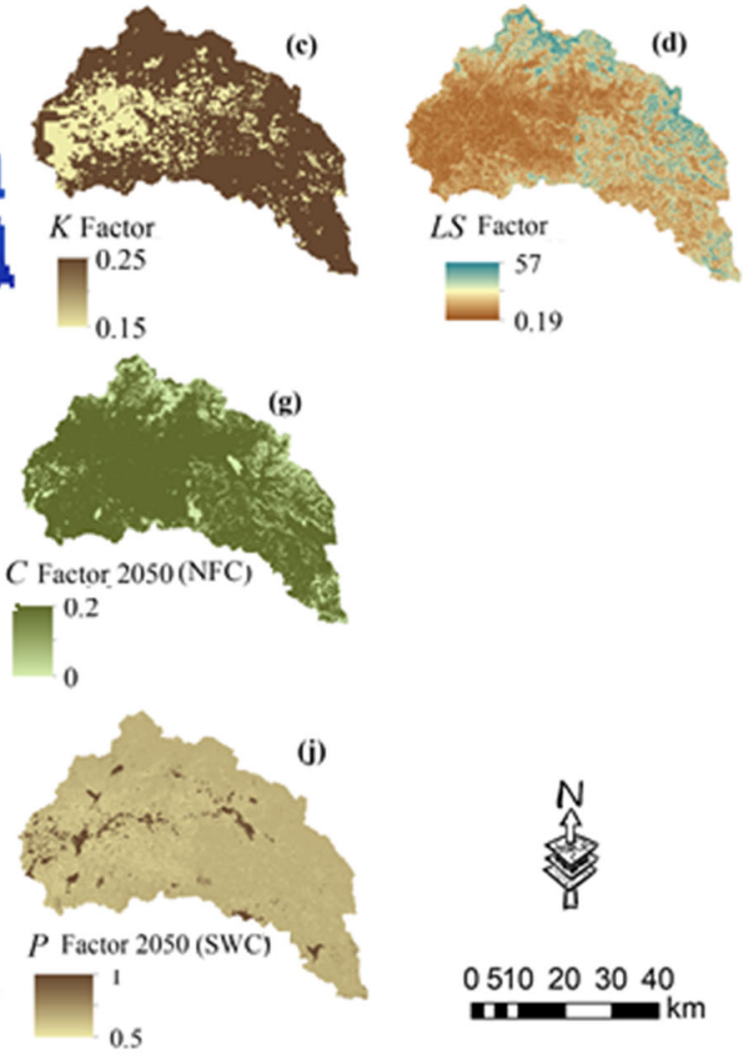

expansion of the native forest cover (NFC, scenario 3 ), h $P$ factor for the baseline condition, $\mathbf{i} P$ factor for the future scenario, and $\mathbf{j} P$ factor for the future scenario after the application of soil and water conservation measures (scenario 4)

located in and around the watershed, whereas the $C$ and $P$ values were generated based on the most recent (2017) landuse data.

\section{Scenario 2: climate and land-use change}

This scenario predicts future soil erosion under the influence of simultaneous climate and land-use changes under the current land-use regimes, without applying any conservation measures. We used mean annual rainfall (2018 to 2050) simulated by the HadGEM2-ES model to generate the map of $R$ values, but generated the map of $C$ values using the land use projected by the CA-Markov model for the year 2050 .

\section{Scenario 3: expansion of native forest cover}

This scenario assesses the effectiveness of afforestation for reducing future soil erosion. Erosion rates in well-vegetated and protected areas are relatively low, ranging from 0.004 to $0.050 \mathrm{t} \mathrm{ha}^{-1}$ year $^{-1}$ (Lal 1994). Forest reduces the rate of soil erosion by stabilizing soils and enhancing their water-holding capacity. Thus, the expansion of native forest cover should significantly reduce the future rate of soil loss in the study area. Based on our field surveys, the current forest type is 
dominated by eucalyptus species with little understory vegetation, which protects the soil poorly, leading to high erosion rates. In contrast, the native forest can have dense understory vegetation; as a result, soil erosion is typically low. However, much of the remaining native forest is seriously degraded because of grazing, and can no longer provide the same degree of protection offered by the intact forest.

In this scenario, we propose increasing the current native forest cover $(<3 \%$ of the area) to $10.5 \%$ in 2050 , mainly in hilly areas with a slope greater than $40 \%$.

\section{Scenario 4: application of physical soil conservation measures}

This scenario evaluates the effectiveness of physical soil conservation measures in reducing soil loss. If effectively implemented, physical soil and water conservation measures such as sloping stone bunds, terraces, and check dams reduce future soil erosion in areas with steep slopes. These types of conservation measures have been widely practiced in northern highland Ethiopia (Tigray Region) and found to be effective in reducing surface runoff, facilitating water infiltration, and minimizing soil erosion (Gebrernichael et al. 2005; Nyssen et al. 2008; Taye et al. 2018). However, Moges and Taye (2017) reported that $10 \%$ or less of the total watershed currently includes soil and water conservation structures, and most of the existing structures have not been maintained properly. In this scenario, we assumed the implementation of physical soil conservation practices in all areas with a slope greater than $20 \%$ (which cover about $34 \%$ of the total catchment as the target zones for the application of physical soil conservation practices).

\section{Scenario 5: combined scenarios}

This scenario aimed to reduce the rate of soil loss by combining expanded native forest cover (scenario 3) with the use of soil and water conservation measures (scenario 4 ). We hypothesized that this combination would reduce soil erosion better than using the two approaches separately. Figure 3 presents the overall methodological framework used for this study.

\section{Results}

\section{Projected climate change}

Compared with the baseline (1973 to 2017) scenario, the mean annual rainfall in the watershed is expected to increase by $17.3 \%$ by the year 2050 (Table 1). The model also predicted that the minimum and maximum temperatures would increase by 2.11 and $2.66{ }^{\circ} \mathrm{C}(25.5$ and $12.2 \%)$, respectively. This agrees with previous studies (e.g., Conway and Schipper 2011; Kassie et al. 2014; Abera et al. 2018; Fentaw et al. 2018) that predicted increasing precipitation and temperatures in other parts of Ethiopia.

\section{Land-use change}

Our model predicts extensive land-use changes in the watershed between 2017 and 2050 (see Supplementary Material Table S5). The built-up areas increased from $21 \mathrm{~km}^{2}$ in 2017 to $56.5 \mathrm{~km}^{2}$ in 2050 (a $169 \%$ increase). The cropland showed a relatively modest increase, from $1685 \mathrm{~km}^{2}$ in 2001 to $1736.5 \mathrm{~km}^{2}$ in 2017 (a $3 \%$ increase), and is projected to increase further, to $1772 \mathrm{~km}^{2}$ in 2050 (a $2 \%$ increase). This relatively small growth can be explained by the fact that almost all potential agricultural areas have already been exploited, and the remaining areas are unsuitable for cultivation. The cropland expansion will take place only at the expense of grasslands and shrublands, which are projected to decrease in area by 66 and 25\%, respectively, between 2017 and 2050. The forest cover showed a slight but continuous increase throughout the study period.
Fig. 3 Framework for the five scenarios used to estimate soil erosion

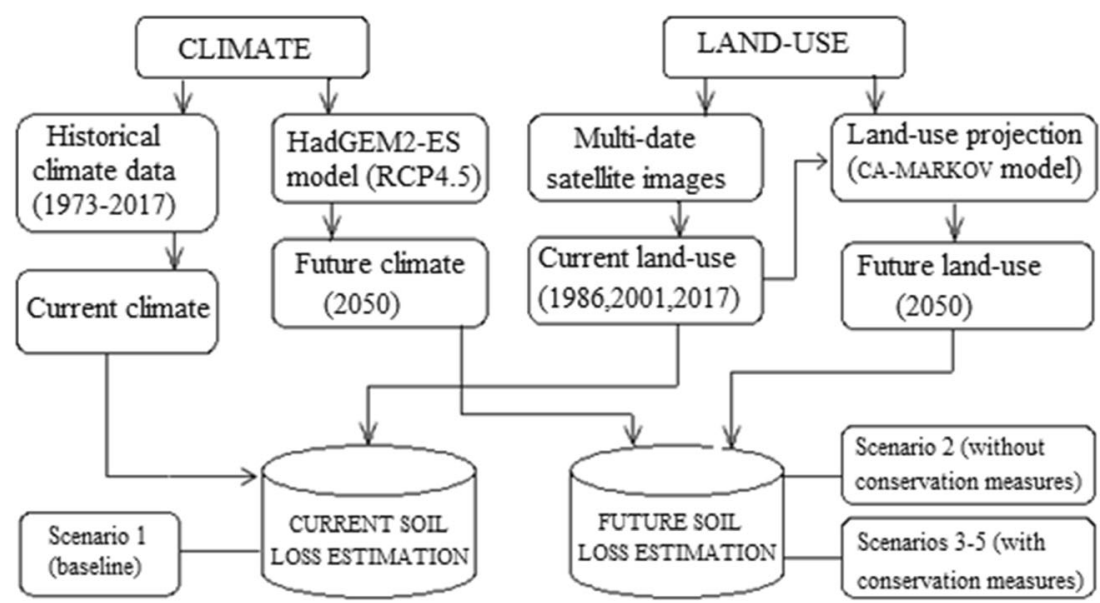


Table 1 The mean annual rainfall and minimum and maximum temperatures in the current baseline situation and in the future scenario

\begin{tabular}{|c|c|c|c|c|c|c|}
\hline \multirow[t]{2}{*}{ Scenarios } & \multicolumn{2}{|l|}{ Rainfall } & \multicolumn{2}{|c|}{ Minimum temperature } & \multicolumn{2}{|c|}{ Maximum temperature } \\
\hline & Mean annual (mm) & Change (\%) & Mean min. $\left({ }^{\circ} \mathrm{C}\right)$ & Change (\%) & Mean max. $\left({ }^{\circ} \mathrm{C}\right)$ & Change (\%) \\
\hline Baseline & 1351 & - & 8.27 & - & 21.78 & - \\
\hline Future & 1585 & 17.3 & 10.38 & 25.5 & 24.43 & 12.2 \\
\hline
\end{tabular}

\section{Modeled soil erosion}

Table 2 presents the mean and total soil loss rates corresponding to the five scenarios. The total annual soil loss for the whole watershed ranged from $7.93 \times 10^{6} \mathrm{t}^{\text {year }}{ }^{-1}$ in 2017 to $9.75 \times 10^{6}$ t year $^{-1}$ in 2050 in scenario 2 (an increase of about $23 \%)$. The mean annual soil loss ranged from $69.6 \mathrm{t} \mathrm{ha}^{-1}$ year $^{-1}$ in 2017 to $78 \mathrm{t} \mathrm{ha}^{-1}$ year $^{-1}$ in scenario 2. The mean annual soil loss of $78 \mathrm{t} \mathrm{ha}^{-1}$ year $^{-1}$ in 2050 (scenario 2) represents an increase of $12 \%$ compared with the baseline period (2017). However, the high mean annual soil loss predicted under scenario 2 could be reduced to less than $45 \mathrm{t} \mathrm{ha}^{-1}$ year $^{-1}$ (a $42 \%$ decrease) by implementation of either conservation measure, with the greatest effect achieved by a combination of both measures in scenario 5 (soil loss reduced to $30.4 \mathrm{t} \mathrm{ha}^{-1}$ year $^{-1}$, a decrease of $61 \%$,).

To identify conservation priorities based on the erosion risk, we classified the estimated soil loss into six levels (FAO 1986; Molla and Sisheber 2017): slight, moderate, high, very high, severe, and very severe (Fig. 4). For all of the designed scenarios, the highest rates of soil loss were observed in the northern, eastern, and southeastern parts of the watershed, whereas the western parts and most of the central parts experienced lower soil loss.

\section{Discussion}

\section{The effect of climate change on soil erosion}

The mean annual soil losses estimated in this study agree with experiment-based estimates by Bewket and Teferi (2009), Yihenew and Yihenew (2013), and Zerihun et al. (2018), which ranged from 49 to $93 \mathrm{t} \mathrm{ha}^{-1}$ year ${ }^{-1}$. The variability in the spatial distribution of soil loss can be attributed to variability in the biophysical components of the watershed, including the topography, rainfall, land use (i.e., surface cover), and soil type. The magnitude of soil loss in the watershed can be evaluated by comparing the estimated soil losses with threshold values that define the soil loss tolerance level. In all five scenarios, more than $50 \%$ of the watershed experienced erosion rates higher than the maximum tolerable level of $18 \mathrm{t} \mathrm{ha}^{-1}$ year $^{-1}$ for Ethiopia (Hurni 1985).

Climate change influences soil erosion in different ways. The most direct and significant influence of climate change is through changes in the erosive power of rainfall (Nearing et al. 2004). Higher rainfall amounts and intensities (i.e., amount per unit time), as well as extreme rainfall events, increase soil loss due to their direct impacts on runoff rates and the mechanics of soil erosion (Li and Fang 2016). Pruski and Nearing (2002) predicted that every $1 \%$ change in rainfall amount could change runoff by $2 \%$ and erosion by $1.7 \%$. Similarly, Zhang (2007) showed that a 4 to $18 \%$ increase in precipitation can increase runoff by 49 to $112 \%$ and soil erosion by 31 to $167 \%$. Therefore, the predicted $17 \%$ increase in rainfall in the Rib watershed is likely to cause a proportionally high increase in runoff and erosion, especially when combined with other factors such as the watershed's poor vegetation cover and limited use of soil and water conservation measures.

Another potential effect of climate change on soil erosion relates to rising temperatures and atmospheric $\mathrm{CO}_{2}$ concentrations. The predicted temperature increase can have both positive and negative effects on soil erosion. As temperature increases, evapotranspiration increases and soil moisture decreases, thereby increasing the soil's water infiltration capacity and reducing runoff and soil erosion (Xu 2003). Moreover, $\mathrm{CO}_{2}$-driven changes in plant biomass production and organic matter decomposition rates may decrease soil erosion by increasing vegetation cover (Mullan 2013). In contrast, plant stress created by high temperatures may increase erosion rates by increasing evaporation, reducing the availability of soil water, and thereby decreasing plant growth (Pruski and Nearing 2002; Li and Fang 2016). An increase in temperature also increases organic matter decomposition rates due to

Table 2 The mean and total soil losses for current baseline scenario (scenario 1) and four future scenarios: 2, current trends without soil conservation measures; 3 , expansion of native forest cover; 4 , use of physical conservation measures; 5, combination of scenarios 3 and 4

\begin{tabular}{lcccrr}
\hline Soil loss & Scenario 1 & Scenario 2 & Scenario 3 & Scenario 4 & Scenario 5 \\
\hline Mean $\left(\mathrm{t} \mathrm{ha}^{-1}\right.$ year $\left.^{-1}\right)$ & 69.6 & 78.00 & 44.50 & 38.00 & 30.4 \\
Total $\left(\right.$ Mt year $\left.^{-1}\right)$ & 7.93 & 9.75 & 7.55 & 5.14 & 3.72 \\
\hline
\end{tabular}



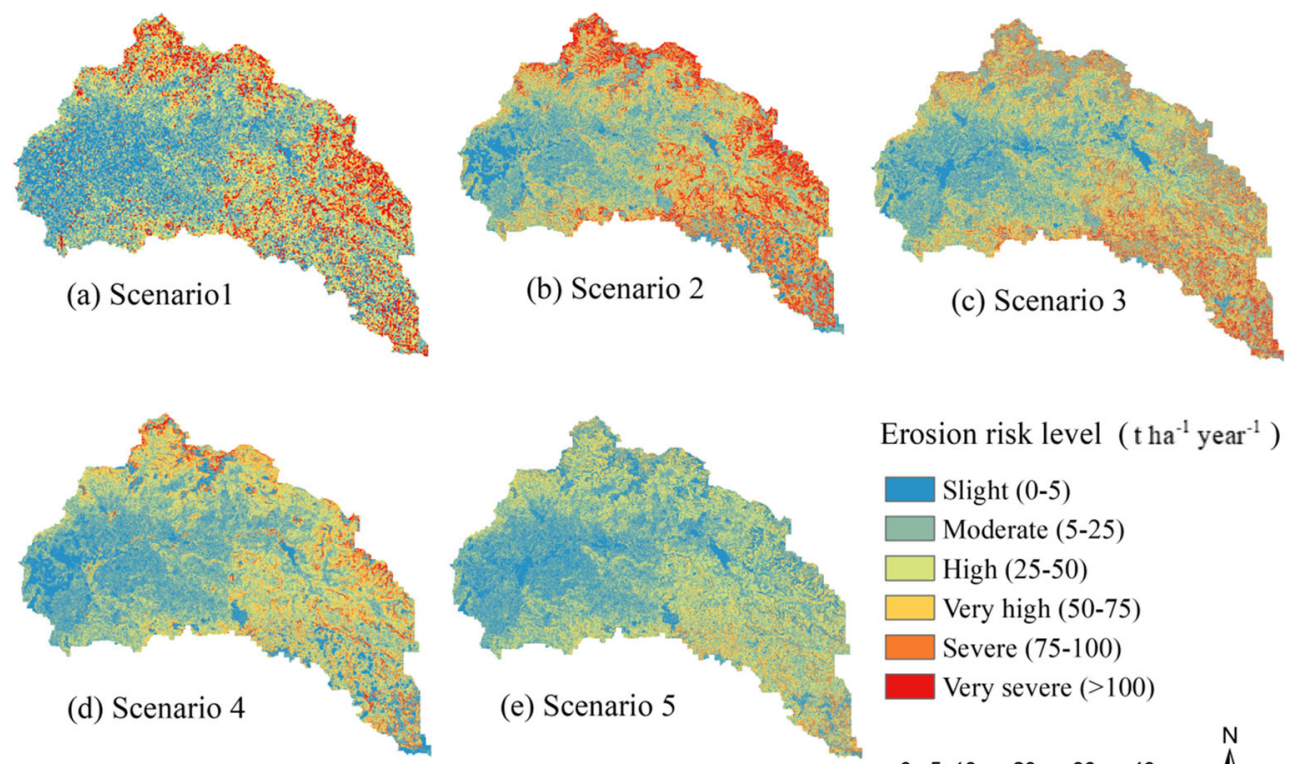

Erosion risk level ( $\mathrm{t} \mathrm{ha}^{-1}$ year $\left.^{-1}\right)$

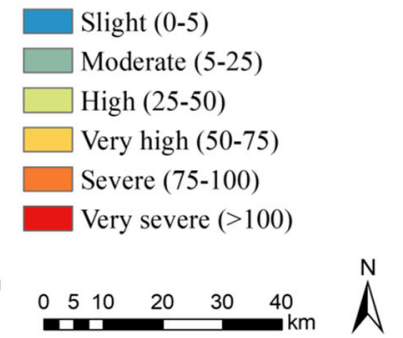

Fig. 4 Soil erosion risk maps corresponding to the five studied scenarios. a Current soil loss for the baseline conditions in 2017 (scenario 1), b future soil loss under the predicted climate and land-use changes but without any conservation actions (scenario 2), $\mathbf{c}$ future soil loss after expansion of native forest cover to reduce erosion (scenario 3), $\mathbf{d}$ future

increased soil microbial activity (Nearing et al. 2004), and this can expose the soil to surface runoff, leading to soil erosion. Williams et al. (1996) note that warm temperatures can also cause soil erosion through changes in land use and crop management practices to accommodate the new climatic regime.

Overall, our simulations suggest that in the absence of measures to reduce runoff, soil erosion in the study area is expected to become more severe, especially in upland areas where soil erosion is already severe, in response to the direct influence of changes in rainfall patterns and the indirect influence of rising temperatures. Under the influence of the region's rapidly growing human population and limited access to advanced agricultural technologies, any climate-induced increase in future soil erosion would significantly decrease the productivity of rainfed subsistence agriculture and jeopardize the livelihood of the watershed's rural community.

\section{The effect of land-use change on soil erosion}

Land-use change is among the major factors that determine the rate of soil erosion. Rapid population growth, a shortage of arable land, and increased demand for food production have significantly intensified the pressure on the land and aggravated land-use change in most parts of highland Ethiopia, including the Rib watershed (Zeleke and Hurni 2001; Meire et al. 2013; Meshesha et al. 2014; Moges and Bhat 2018). Conversion of natural vegetation (native forest, shrubs, and grasses) to cropland was the major land-use change observed in the Rib watershed. Zhou et al. (2008) found that watersheds soil loss after application of soil and water conservation measures (scenario 4), and e future soil loss under a combination of the conservation actions in scenarios 3 and 4 (scenario 5). Future values are predicted for 2050

tend to experience high rates of erosion when more than $30 \%$ of the soil is exposed, whereas vegetation cover of more than $78 \%$ can greatly reduce erosion by water. In the Rib watershed, however, less than $10 \%$ of the total area is covered by natural vegetation, even though this vegetation is located primarily in areas dominated by rugged topography and steep slopes, which are unsuitable for agriculture and construction of built-up areas.

Natural vegetation cover affects the processes that govern the rate of soil erosion in various ways. For example, this vegetation tends to do a better job of protecting the soil because the higher species diversity results in higher vegetation cover, greater deposition of organic matter (e.g., leaf litter), and more complete exploitation of the whole soil volume by plant roots than would be the case with artificial vegetation communities. Removing natural vegetation increases soil erosion by reducing the protection of the soil, litter production, and organic matter accumulation, leading to a higher value of $C$ (Wijitkosum 2012). Litter and organic matter not only directly protect the surface soil from the kinetic energy of falling raindrops and the resulting splash erosion, but also conserve surface water (Wei et al. 2007). Converting natural vegetation to other land-use types also diminishes the role of plant root systems, which reduce soil erodibility by improving intrinsic properties of the soil such as aggregate stability, infiltration capacity, bulk density, texture, organic matter and chemical contents, and shear strength (Gyssels et al. 2005).

The rate of soil loss was highest in croplands followed by non-native forest and shrubland. The high soil loss in cropland 
results from widespread agricultural activities combined with poor soil conservation practices. Our field observations revealed that most of the croplands in the watershed are located in areas dominated by rugged terrain, leading to the cultivation of steep slopes; the exposed soil surface at such sites would greatly increase soil erosion compared with vegetated surfaces. The high erosion rates observed in the forested land have several possible explanations. In contrast with the findings of studies in other parts of Ethiopia (e.g., Haregeweyn et al. 2012; Hassen and Assen 2018), we found a slight but continuous growth of forest cover during the study period. However, our field observations and interviews revealed that the increase in forest cover that we observed was not because of the growth of native forest cover, but rather was due to expansion of the area of eucalyptus plantations. Eucalyptus has been introduced in most parts of highland Ethiopia as an alternative to native species (Nyssen et al. 2009). Moges and Bhat (2018) report that these trees are the main source of income and fuelwood in the Rib watershed, which strongly encourages residents to introduce or expand the area of eucalyptus trees in their farmland. Soils under eucalyptus trees become more acidic and have lower organic matter and nutrient contents than the soils under native forests (Liang et al. 2016), leading to low soil porosity, high surface runoff, and severe erosion. Therefore, it is essential to convert eucalyptus plantations to native forests to improve soil conservation in the watershed.

Another possible reason for the high soil loss in forests is that the few remnant native forests in the watershed are located in hilly areas with steep slopes. This topography considerably increases soil erosion due to its direct influences on surface runoff, drainage, and sedimentation rates (Dessalegn et al. 2014). Haigh et al. (1995) suggest that a minimum of $60 \%$ of forest cover is required to effectively prevent soil erosion in forested land. In the Rib watershed, however, the residual native forests are sparsely vegetated and mostly used for cattle grazing, which can also exacerbate erosion due to the removal of vegetation by grazing and the damage to the soil structure caused by the hooves of the cattle.

\section{The effectiveness of potential conservation measures}

To test the effectiveness of the soil conservation measures, we designed two conservation scenarios and evaluated their effectiveness, alone or when combined, for reducing future soil erosion. We found that expansion of the native forest cover (scenario 3) can reduce the total annual soil loss by more than $22 \%$ compared with future soil loss rates without any soil conservation measures (scenario 2). This agrees with the findings of Tesfahunegn et al. (2012), who demonstrated that afforestation was capable of reducing runoff and sediment yields by up to $51 \%$ in highly degraded areas of northern Ethiopia. Zhang et al. (2016) reported that in small watersheds, native vegetation can reduce runoff and sedimentation by 44 and $83 \%$, respectively. In addition, it is important to integrate afforestation with the use of exclosures to protect the vegetation against human interference and grazing damage (Birhane et al. 2017). Such exclosures are a common vegetation restoration tool in highland Ethiopia, as they enhance the composition, diversity, and density of the vegetation in highly degraded areas, and thus promote the regeneration of natural forests (Mekuria et al. 2011; Birhane et al. 2017).

Our results also show that the construction of physical soil and water conservation measures such as terraces and sloping stone bunds (scenario 4) can reduce total soil loss of the watershed by $47 \%$ compared with the soil loss with no soil conservation measures (scenario 2). Such physical measures not only intercept runoff, increase infiltration, and trap sediments, but also reduce the slope of the land between adjacent structures, thereby slowing runoff and reducing its erosive power (Nyssen et al. 2007). An experimental study by Melaku et al. (2018) indicated that soil and stone bunds can notably reduce the slope length where they are implemented within a watershed and provide retention space for sediments; as a result, they gradually reduce the original slope and make it more suitable for cultivation by trapping nutrient-rich-eroded sediments. Terraces work similarly. Combining terraces and stone bunds with suitable crops can further reduce the ability of a steep slope to increase soil erosion (Descheemaeker et al. 2006). In addition, Lemessa (2001) and Woldemariam et al. (2018) reported that khat (Catha edulis), a perennial cash crop, can potentially reduce soil erosion by minimizing the rainfall's runoff velocity in the highlands of Ethiopia.

The total annual soil loss estimated under scenario 2 could be reduced by $62 \%$ by combining afforestation with the use of physical soil and water conservation measures (scenario 5). On this basis, we recommend that local governments encourage the combined use of the two conservation measures to reduce future soil loss rather than applying them separately. Tesfahunegn et al. (2012) found that the application of soil conservation measures alone was less effective than combining these measures with increased afforestation. Application of soil conservation measures such as intercropping, stone bunds, and afforestation individually is no longer sufficient to sustain landscape management efforts, but combining several of these nature-based solutions can potentially enhance the soil's health and its functions, thereby maintaining or restoring the provision of ecosystem services (Keesstra et al. 2018). It is important to note that although we found some evidence of soil conservation measures being used in our field research, the physical structures were often poorly maintained. Thus, to ensure that these structures provide their full potential benefit, local governments or the national government should increase agricultural extension activities to teach farmers the importance of maintaining these structures and should consider subsidizing the cost of this maintenance. 


\section{Limitations of our soil erosion model}

GIS tools are useful for modeling complex relationships between land use, soil erosion, and topography, and when they are combined with a soil loss model such as RUSLE, they can contribute greatly to sustainable land-use planning (Kull et al. 2005). However, several factors create uncertainty in our modeling results, including the absence of reliable data to parameterize the models and uncertainties in the climate model outputs that drive the soil loss model (Alewell et al. 2019). The socioeconomic and political conditions in a study area will also strongly affect the land-use changes. Because we could not obtain such data for our study area, the predicted future land-use patterns were based on the biophysical characteristics of the watershed. Although climate models are becoming more accurate, predictions for small study areas differ between models ( $\mathrm{O}^{\prime} \mathrm{Neal}$ et al. 2005). To reduce such discrepancies, it may be worthwhile to combine the outputs of multiple models instead of depending on a single model's outputs. In this study, however, we performed our climate predictions using a single model (HadGEM2-ES).

Another possible limitation of our study was the lack of measured sediment yields or soil loss rates to validate the simulated outputs. However, we accounted for the results of previous studies and for information gathered during our field observations to compare the severity and spatial distribution of the estimated and actual soil loss in the watershed. Meshesha et al. (2012) found good reliability and validity of RUSLE outputs, with an overall accuracy of erosion estimates of $71.1 \%$. Further field-based studies of sediment transport and deposition could be used to calibrate RUSLE and improve the land use and management decisions in the study area.

\section{Conclusions}

In this study, we analyzed the potential impacts of climate and land-use changes on soil erosion and evaluated the potential effectiveness of simple conservation measures. Our modeling predicted considerable changes in climate and land use in the watershed by 2050 . We predict a continuous and substantial increase in cropland at the expense of native forest, grassland, and shrubland. Precipitation and temperatures will increase by 2050 , leading to direct and indirect effects that will increase soil erosion if preventive measures are not implemented. The rapid human population growth and high pressure that will be placed on limited watershed resources may increase future soil loss compared with the predicted rates. Therefore, it is essential to begin implementing conservation measures to minimize soil erosion and stabilize the landscape. Our modeling suggests that expansion of the native forest cover and implementation of physical soil conservation structures can greatly reduce soil erosion, but the effects will be greatest when these measures are combined. However, additional measures may be necessary to further reduce erosion.

Our results demonstrate that the combination of models we employed has a high potential for predicting future soil erosion and evaluating potential conservation measures to mitigate the effects of climate and land-use change. Our results can be used to increase the awareness of the farmers about the causes, magnitudes, and effects of soil loss and motivate them to investigate soil conservation measures. However, government investments and support may be required to encourage farmers to change their practices. Our results will also help decision-makers to improve their planning of future land use and to identify priority soil conservation to improve the sustainability of watershed management. Additional studies on the economic feasibility of the proposed conservation measures could help the farmers and decision-makers to better prioritize the optimal soil conservation areas and methods.

Acknowledgments The corresponding author is grateful to the Landscape Geoinformatics Lab of the University of Tartu, where all of the geospatial analysis was performed. We thank the journal's anonymous reviewers, whose comments helped to improve the quality of our paper.

Funding information This study was supported by the Dora Plus Programme of the Government of Estonia (Grant No. 2-1.17 / LT / 1939 11/01/2018), the Marie Skłodowska-Curie Actions individual fellowships under the Horizon 2020 Programme grant agreement number 795625, the Mobilitas Pluss Postdoctoral Researcher Grant number MOBJD233 and PRG352 of the Estonian Research Council (ETAG), and by the European Regional Development Fund (Centre of Excellence EcolChange).

\section{References}

Abera K, Crespo O, Seid J, Mequanent F (2018) Simulating the impact of climate change on maize production in Ethiopia, East Africa. Environ Syst Res 7:1-12. https://doi.org/10.1186/s40068-0180107-z

Alewell C, Borrelli P, Meusburger K, Panagos P (2019) Using the USLE: chances, challenges and limitations of soil erosion modelling. Int Soil Water Conserv Res 7:203-225. https://doi.org/10.1016/j. iswcr.2019.05.004

Alexakis DD, Agapiou A, Hadjimitsis DG, Retalis A (2013) Optimizing statistical classification accuracy of satellite remotely sensed imagery for supporting fast flood hydrological analysis. Acta Geophys 60:959-984. https://doi.org/10.2478/s11600-012-0025-9

Asselman NEM, Middelkoop H, van Dijk PM (2003) The impact of changes in climate and land use on soil erosion, transport, and deposition of suspended sediment in the River Rhine. Hydrol Process 17:3225-3244. https://doi.org/10.1002/hyp.1384

Basaran M, Erpul G, Tercan AE, Çanga MR (2007) The effects of land use changes on some soil properties in İndağı Mountain PassÇankırı, Turkey. Environ Monit Assess 136:101-119. https://doi. org/10.1007/s10661-007-9668-4 
Bekele D, Alamirew T, Kebede A, Zeleke G, Melesse MA (2018) Modeling climate change impact on the hydrology of Keleta Watershed in the Awash River Basin, Ethiopia. Environ Model Assess 24(1):95-107. https://doi.org/10.1007/s10666-018-9619-1

Bewket W, Teferi E (2009) Assessment of soil erosion hazard and prioritization for treatment at the watershed level: case study in the Chemoga watershed, Blue Nile basin, Ethiopia. Land Degrad Dev 20(6):609-622. https://doi.org/10.1002/ldr.944

Bhandari KP, Aryal J, Darnsawasdi R (2015) A geospatial approach to assessing soil erosion in a watershed by integrating socio-economic determinants and the RUSLE model. Nat Hazards 75(1):321-342. https://doi.org/10.1007/s11069-014-1321-2

Birhane E, Mengistu T, Seyoum Y, Hagazi N, Putzel L, Rannestad MM, Kassa H (2017) Exclosures as forest and landscape restoration tools: lessons from Tigray Region, Ethiopia. Int For Rev 19:37-50. https:// doi.org/10.1505/146554817822330498

Breure AM, Lijzen JPA, Maring L (2018) Soil and land management in a circular economy. Sci Total Environ 624:1125-1130. https://doi.org/ 10.1016/j.scitotenv.2017.12.137

Brhane G, Mekonen K (2009) Estimating soil loss using universal soil loss equation (USLE) for soil conservation planning at Medego watershed, northern Ethiopia. J Am Sci 5(1):58-69

Bussi G, Francés F, Horel E, López-Tarazón JA, Batalla RJ (2014) Modelling the impact of climate change on sediment yield in a highly erodible Mediterranean catchment. J Soils Sediments 14: 1921-1937. https://doi.org/10.1007/s11368-014-0956-7

Bussi G, Dadson SJ, Prudhomme C, Whitehead PG (2016) Modelling the future impacts of climate and land-use change on suspended sediment transport in the River Thames (UK). J Hydrol 542:357-372. https://doi.org/10.1016/j.jhydrol.2016.09.010

Cebecauer T, Hofierka J (2008) The consequences of land cover changes on soil erosion distribution in Slovakia. Geomorphology 98:187198. https://doi.org/10.1016/j.proenv.2013.06.101

Chen H, El Garouani A, Lewis LA (2008) Modelling soil erosion and deposition within a Mediterranean mountainous environment utilizing remote sensing and GIS-Wadi Tlata, Morocco. Geogr Helv 63: 36-47. https://doi.org/10.5194/gh-63-36-2008; https://www.geogrhelv.net/63/36/2008/gh-63-36-2008.pdf. Accessed 12 October 2018

Conway D, Schipper ELF (2011) Adaptation to climate change in Africa: challenges and opportunities identified from Ethiopia. Glob Environ Chang 21:227-237. https://doi.org/10.1016/j.gloenvcha.2010.07. 013

Descheemaeker K, Nyssen J, Poesen J, Raes D, Haile M, Muys B, Deckers S (2006) Runoff on slopes with restoring vegetation: a case study from the Tigray highlands, Ethiopia. J Hydrol 331:219-241. https://doi.org/10.1016/j.jhydrol.2006.05.015

Dessalegn D, Beyene S, Ram N, Walley F, Gala TS (2014) Effects of topography and land use on soil characteristics along the toposequence of Ele watershed in southern Ethiopia. Catena 115: 47-54. https://doi.org/10.1016/j.catena.2013.11.007

Eastman JR (2012) IDRISI Selva Tutorial. IDRISI Production, Clark Labs-Clark University, Worcester, $\mathrm{p} 45$

ESRI (2011) ArcGIS Desktop: Release 10. Environmental Systems Research Institute, Redlands

FAO (1986) Natural resources and the human environment for food and agriculture in Africa, FAO Environment and Energy Paper No. 6. Food and Agriculture Organization of the United Nations, Rome

FAO (2010) Global forest resources assessment main report. Food and Agriculture Organization of the United Nations, Rome

Farhan Y, Nawaiseh S (2015) Spatial assessment of soil erosion risk using RUSLE and GIS techniques. Environ Earth Sci 74:4649-4669. https://doi.org/10.1007/s12665-015-4430-7

Fentaw F, Hailu D, Nigussie A, Melesse AM (2018) Climate change impact on the hydrology of Tekeze Basin, Ethiopia: projection of rainfall-runoff for future water resources planning. Water Conserv Sci Eng 3(4):267-278. https://doi.org/10.1007/s41101-018-0057-3
Ferreira V, Samora-Arvela A, Panagopoulos T (2016) Soil erosion vulnerability under scenarios of climate land-use changes after the development of a large reservoir in a semi-arid area. J Environ Plan Manag 59:1238-1256. https://doi.org/10.1080/09640568.2015. 1066667

Gebrernichael D, Nyssen J, Poesen J, Deckers J, Haile M, Govers G, Moeyersons J (2005) Effectiveness of stone bunds in controlling soil erosion on cropland in the Tigray Highlands, northern Ethiopia. Soil Use Manag 21:287-297. https://doi.org/10.1111/j. 1475-2743.2005.tb00401.x

Gyssels G, Poesen J, Bochet E, Li Y (2005) Impact of plant roots on the resistance of soils to erosion by water: a review. Prog Phys Geogr 29:189-217. https://doi.org/10.1191/0309133305pp443ra

Haigh MJ, Rawat JS, Rawat MS, Bartarya SK, Raj SP (1995) Interactions between forest and landslide activity along new highways in the Kumaun Himalaya. For Ecol Manag 78:173-189. https://doi.org/ 10.1016/0378-1127(95)03584-5

Haregeweyn N, Berhe A, Tsunekawa A, Tsubo M, Meshesha DT (2012) Integrated watershed management as an effective approach to curb land degradation: a case study of the Enabered watershed in northern Ethiopia. Environ Manag 50:1219-1233. https://doi.org/10.1007/ s00267-012-9952-0

Haregeweyn N, Tsunekawa A, Poesen J, Tsubo M, Meshesha DT, Fenta AA, Jan N, Adgo E (2017) Comprehensive assessment of soil erosion risk for better land use planning in river basins: case study of the Upper Blue Nile River. Sci Total Environ 574:95-108. https://doi. org/10.1016/j.scitotenv.2016.09.019

Hassen EE, Assen M (2018) Land use/cover dynamics and its drivers in Gelda catchment, Lake Tana watershed, Ethiopia. Environ Syst Res 6:1-13. https://doi.org/10.1186/s40068-017-0081-x

Hurni H (1985) Soil conservation manual for Ethiopia. First draft. Ministry of Agriculture, Natural Resources Conservation and Development Department. Community Forests and Soil Conservation Development Department, Addis Ababa

Kassie BT, Rötter RP, Hengsdijk H, Asseng S, Van Ittersum MK, Kahiluoto H, Van Keulen H (2014) Climate variability and change in the Central Rift Valley of Ethiopia: challenges for rainfed crop production. J Agric Sci 152:58-74. https://doi.org/10.1017/ S0021859612000986

Keesstra S, Nunes J, Novara A, Finger D, Avelar D, Kalantari Z, Cerdà A (2018) The superior effect of nature based solutions in land management for enhancing ecosystem services. Sci Total Environ. https://doi.org/10.1016/j.scitotenv.2017.08.077

Klik A, Eitzinger J (2010) Impact of climate change on soil erosion and the efficiency of soil conservation practices in Austria. J Agric Sci 148:529-541. https://doi.org/10.1017/S0021859610000158

Kull A, Kull A, Uuemaa E, Kuusemets V, Mander Ü (2005) Modelling of excess nitrogen in small rural catchments. Agric Ecosyst Environ 108:45-56. https://doi.org/10.1016/j.agee.2004.12.011

Lal R (1994) Water management in various crop production systems related to soil tillage. Soil Tillage Res 30:169-185. https://doi.org/ 10.1016/0167-1987(94)90004-3

Lambin EF, Turner BL, Geist HJ, Agbola SB, Angelsen A, Bruce JW, Coomes OT, Dirzo R, Fischer G, Folke C, George PS, Homewood $\mathrm{K}$, Imbernon J, Leemans R, Li X, Moran EF, Mortimore M, Ramakrishnan PS, Richards JF, Skanes H, Steffen W, Stone GD, Svedin U, Veldkamp TA, Vogel C, Xu J (2001) The causes of landuse and land-cover change: moving beyond the myths. Glob Environ Chang 11:261-269. https://doi.org/10.1016/S09593780(01)00007-3

Lemessa D (2001) Khat (Catha edulis): botany, distribution, cultivation, usage and economics in Ethiopia. UN-Emergencies Unit for Ethiopia, Addis Ababa, Ethiopia

Li Z, Fang H (2016) Impacts of climate change on water erosion: a review. Earth-Sci Rev 163:94-117. https://doi.org/10.1016/j. earscirev.2016.10.004 
Liang J, Reynolds T, Wassie A, Collins C, Wubalem A (2016) Effects of exotic Eucalyptus spp. plantations on soil properties in and around sacred natural sites in the northern Ethiopian highlands. AIMS Agric Food 1(2):175-193. https://doi.org/10.3934/agrfood.2016.2.175

Meire E, Frankl A, De Wulf A, Haile M, Deckers J, Nyssen J (2013) Land use and cover dynamics in Africa since the nineteenth century: warped terrestrial photographs of North Ethiopia. Reg Environ Chang 13:717-737. https://doi.org/10.1007/s10113-012-0347-9

Mekuria W, Veldkamp E, Tilahun M, Olschewski R (2011) Economic valuation of land restoration: the case of exclosures established on communal grazing lands in Tigray. Land Degrad Dev 22:334-344. https://doi.org/10.1002/ldr.1001

Mekuriaw A, Heinimann A, Zeleke G, Hurni H (2018) Factors influencing the adoption of physical soil and water conservation practices in the Ethiopian highlands. Int Soil Water Conserv Res 6:23-30. https://doi.org/10.1016/j.iswcr.2017.12.006

Melaku ND, Renschler CS, Flagler J, Bayu W, Klik A (2018) Integrated impact assessment of soil and water conservation structures on runoff and sediment yield through measurements and modeling in the northern Ethiopian highlands. Catena 169:140-150. https://doi.org/ 10.1016/j.catena.2018.05.035

Meshesha DT, Tsunekawa A, Tsubo M, Haregeweyn N (2012) Dynamics and hotspots of soil erosion and management scenarios of the Central Rift Valley of Ethiopia. Int J Sediment Res 27:84-99. https://doi.org/10.1016/S1001-6279(12)60018-3

Meshesha DT, Tsunekawa A, Tsubo M, Ali SA, Haregeweyn N (2014) Land-use change and its socio-environmental impact in eastern Ethiopia's highland. Reg Environ Chang 14:757-768. https://doi. org/10.1007/s10113-013-0535-2

Moges DM, Bhat HG (2017) Integration of geospatial technologies with RUSLE for analysis of land use/cover change impact on soil erosion: case study in Rib watershed, north-western highland Ethiopia. Environ Earth Sci 76:765-714. https://doi.org/10.1007/s12665-0177109-4

Moges DM, Bhat HG (2018) An insight into land use and land cover changes and their impacts in Rib watershed, north-western highland Ethiopia. Land Degrad Dev 29(10):3317-3330. https://doi.org/10. 1002/ldr.3091

Moges DM, Taye AA (2017) Determinants of farmers' perception to invest in soil and water conservation technologies in the northwestern highlands of Ethiopia. Int Soil Water Conserv Res 5:5661. https://doi.org/10.1016/j.iswcr.2017.02.003

Mohammad AG, Adam MA (2010) The impact of vegetative cover type on runoff and soil erosion under difference land uses. Catena 81:97103. https://doi.org/10.1016/j.catena.2010.01.008

Molla T, Sisheber B (2017) Estimating soil erosion risk and evaluating erosion control measures for soil conservation planning at Koga watershed in the highlands of Ethiopia. Solid Earth 8:13-25. https://doi.org/10.5194/se-8-13-2017

Moore ID, Burch FJ (1986) Physical basic of the length-slope factor in the universal soil loss equation. Soil Sci Soc Am J 50:1294-1298. https://doi.org/10.2136/sssaj1986.03615995005000050042x

Mullan D (2013) Soil erosion under the impacts of future climate change: assessing the statistical significance of future changes and the potential on-site and off-site problems. Catena 109:234-246. https:// doi.org/10.1016/j.catena.2013.03.007

Nearing M, Pruski F, O’Neal MR (2004) Expected climate change impacts on soil erosion rates: a review. J Soil Water Conserv 59(1):4350

Nigussie Y, van der Werf E, Zhu X, Simane B, van Ierland EC (2018) Evaluation of climate change adaptation alternatives for smallholder farmers in the Upper Blue-Nile Basin. Ecol Econ 151:142-150. https://doi.org/10.1016/j.ecolecon.2018.05.006

Nunes JP, Seixa J, Keizer JJ (2013) Modeling the response of withinstorm runoff and erosion dynamics to climate change in two Mediterranean watersheds: a multimodel, multi-scale approach to scenario design and analyses. Catena 102:27-39. https://doi.org/ 10.1016/j.catena.2011.04.001

Nyssen J, Poesen J, Gebremichael D, Vancampenhout K, D'aes M, Yihdego G, Govers G, Leirs H, Moeyersons J, Naudts J, Haregeweyn N, Haile M, Deckers J (2007) Interdisciplinary onsite evaluation of stone bunds to control soil erosion on cropland in northern Ethiopia. Soil Tillage Res 94:151-163. https://doi.org/ 10.1016/j.still.2006.07.011

Nyssen J, Poesen J, Moeyersons J, Haile M, Deckers J (2008) Dynamics of soil erosion rates and controlling factors in the northern Ethiopian highlands - towards a sediment budget. Earth Surf Process Landf 33:695-711. https://doi.org/10.1002/esp.1569

Nyssen J, Poesen J, Haile M, Moeyersons J, Deckers J, Hurni H (2009) Effects of land use and land cover on sheet and rill erosion rates in the Tigray highlands, Ethiopia. Zeit Für Geomorphol 53:171-197. https://doi.org/10.1127/0372-8854/2009/0053-0171

O'Neal MR, Nearing MA, Vining RC, Southworth J, Pfeifer RA (2005) Climate change impacts on soil erosion in Midwest United States with changes in crop management. Catena 61:165-184. https://doi. org $/ 10.1016 /$ j.catena.2005.03.003

Paroissien J-B, Darboux F, Couturier A, Devillers B, Mouillot F, Raclot D, Le Bissonnais Y (2015) A method for modeling the effects of climate and land use changes on erosion and sustainability of soil in a Mediterranean watershed (Languedoc, France). J Environ Manag 150:57-68. https://doi.org/10.1016/j.jenvman.2014.10.0344

Pereira P, Bogunovic I, Muñoz-Rojas M, Brevik EC (2018) Soil ecosystem services, sustainability, valuation, and management. Curr Opin Environ Sci Health 5:7-13. https://doi.org/10.1016/j.coesh.2017.12. 003

Plangoen P, Babel M, Clemente R, Shrestha S, Tripathi N (2013) Simulating the impact of future land use and climate change on soil erosion and deposition in the Mae Nam Nan sub-catchment, Thailand. Sustainability 5:3244-3274. https://doi.org/10.3390/ su508324

Prasannakumar V, Vijith H, Abinod S, Geetha N (2012) Estimation of soil erosion risk within a small mountainous sub-watershed in Kerala, India, using revised universal soil loss equation (RUSLE) and geoinformation technology. Geosci Front 3:209-215. https://doi.org/10. 1016/j.gsf.2011.11.003

Pruski FF, Nearing MA (2002) Climate-induced changes in erosion during the 21st century for eight U.S. locations: climate-induced changes in erosion. Water Resour Res 38:34-1-34-11. https://doi.org/10. 1029/2001WR000493

Renard KG, Foster GR, Weesies GA, McCool DK, Yoder DC (Coordinators) (1997) Predicting Soil Erosion by Water: A guide to conservation planningwith the Revised Universal Soil Loss Equation (RUSLE). USDA Agricultural Handbook No. 703, 404 pp. Available at https://www.ars.usda.gov/ARSUserFiles/ 64080530/RUSLE/AH 703.pdf

Routschek A, Schmidt J, Kreienkamp F (2014) Impact of climate change on soil erosion - a high-resolution projection on catchment scale until 2100 in Saxony/Germany. Catena 121:99-109. https://doi. org/10.1016/j.catena.2014.04.019

Saaty TL (1980) The analytic hierarchy process. McGraw-Hill, New York, USA

Simonneaux V, Cheggour A, Deschamps C, Mouillot F, Cerdan O, Le Bissonnais Y (2015) Land use and climate change effects on soil erosion in a semi-arid mountainous watershed (High Atlas, Morocco). J Arid Environ 122:64-75. https://doi.org/10.1016/j. jaridenv.2015.06.002

Tadesse L, Suryabhagavan KV, Sridhar G, Legesse G (2017) Land use and land cover changes and soil erosion in Yezat Watershed, North Western Ethiopia. Int Soil Water Conserv Res 5:85-94. https://doi. org/10.1016/j.iswcr.2017.05.004 
Tamene L, Vlek PLG (2008) Soil erosion studies in northern Ethiopia. In: Braimoh AK, Vlek PLG (eds) Land use and soil resources. Springer, Dordrecht

Taye G, Vanmaercke M, Poesen J, Van Wesemael B, Tesfaye S, Teka D, Nyssen J, Deckers J, Haregeweyn N (2018) Determining RUSLE Pand $\mathrm{C}$-factors for stone bunds and trenches in rangeland and cropland, North Ethiopia. Land Degrad Dev 29:812-824. https://doi.org/ $10.1002 / \mathrm{ldr} .2814$

Tesfahunegn GB, Vlek PLG, Tamene L (2012) Management strategies for reducing soil degradation through modeling in a GIS environment in northern Ethiopia catchment. Nutr Cycl Agroecosyst 92: 255-272. https://doi.org/10.1007/s10705-012-9488-y

Teshome A, de Graaff J, Kessler A (2016) Investments in land management in the north-western highlands of Ethiopia: the role of social capital. Land Use Policy 57:215-228. https://doi.org/10.1016/j. landusepol.2016.05.019

Volk M, Möller M, Wurbs D (2010) A pragmatic approach for soil erosion risk assessment within policy hierarchies. Land Use Policy 27: 997-1009. https://doi.org/10.1016/j.landusepol.2009.12.011

Wei W, Chen L, Fu B, Huang Z, Wu D, Gui L (2007) The effect of land uses and rainfall regimes on runoff and soil erosion in semi-arid loess hilly area, China. J Hydrol 335:247-258. https://doi.org/10. 1016/j.jhydrol.2006.11.016

Wijitkosum S (2012) Impacts of land use changes on soil erosion in $\mathrm{Pa}$ Deng sub-district, adjacent area of Kaeng Krachan National Park, Thailand. Soil Water Res 7:10-17. https://doi.org/10.17221/32/ 2011-SWR

Williams J, Nearing M, Nicks A, Skidmore E, Valentin C, King K, Savabi R (1996) Using soil erosion models for global change studies. J Soil Water Conserv 51(5):381-385. http://www.jswconline.org/content/ 51/5/381.full.pdf+html. Accessed 12 October 2018

Wischmeier WH, Smith DD (1978) Predicting rainfall erosion losses: a guide to conservation planning. Agriculture Handbook no. 537, USDA Science and Education Administration, Washington, p 163

Woldemariam G, Iguala A, Tekalign S, Reddy R (2018) Spatial modeling of soil erosion risk and its implication for conservation planning: the case of the Gobele Watershed, East Hararghe Zone, Ethiopia. Land 7:25. https://doi.org/10.3390/land7010025

$\mathrm{Xu} \mathrm{J}$ (2003) Sediment flux to the sea as influenced by changing human activities and precipitation: example of the Yellow River, China. Environ Manag 31(3):0328-0341. https://doi.org/10.1007/s00267002-2828-y

Yihenew GS, Yihenew B (2013) Costs of nutrient losses in priceless soils eroded from the highlands of northwestern Ethiopia. J Agric Sci 5: 1916-1952. https://doi.org/10.5539/jas.v5n7p227

Zeleke G, Hurni H (2001) Implications of land use and land cover dynamics for mountain resource degradation in the northwestern Ethiopian highlands. Mt Res Dev 21:184-191. https://doi.org/10. 1659/0276-4741(2001)021[0184:IOLUAL]2.0.CO;2

Zerihun M, Mohammedyasin MS, Sewnet D, Adem AA, Lakew M (2018) Assessment of soil erosion using RUSLE, GIS and remote sensing in NW Ethiopia. Geoderma Reg 12:83-90. https://doi.org/ 10.1016/j.geodrs.2018.01.002

Zhang XC (2007) A comparison of explicit and implicit spatial downscaling of GCM output for soil erosion and crop production assessments. Clim Chang 84(3):337-363. https://doi.org/10.1007/s10584007-9256-1

Zhang X, Yu X, Wu S, Cao W (2008) Effects of changes in land use and land cover on sediment discharge of runoff in a typical watershed in the hill and gully loess region of Northwest China. Front For China 3:334-341. https://doi.org/10.1007/s11461-008-0056-1

Zhang W, Hu G, Dang Y, Weindorf DC, Sheng J (2016) Afforestation and the impacts on soil and water conservation at decadal and regional scales in Northwest China. J Arid Environ 130:98-104. https://doi. org/10.1016/j.jaridenv.2016.03.003

Zhou P, Luukkanen O, Tokola T, Nieminen J (2008) Effect of vegetation cover on soil erosion in a mountainous watershed. Catena 75:319 325. https://doi.org/10.1016/j.catena.2008.07.010

Publisher's note Springer Nature remains neutral with regard to jurisdictional claims in published maps and institutional affiliations. 